\title{
Land Reform In Turkmenistan: Does It Work?
}

Rimma Gluhih, (E-mail: rgluhih@bgumail.bgu.ac.il), Ben-Gurion University of the Negev, Israel Moshe Schwartz, (E-mail: moshesc@ bgumail.bgu.ac.il), Ben-Gurion University of the Negev, Israel Zvi Lerman, (E-mail: lerman@agri.huji.ac.il), The Hebrew University, Israel

\begin{abstract}
Turkmenistan is one of the 25 former socialist countries in Europe and Central Asia that embarked on a transition from plan to market in the early 1990s. In agriculture, the transition was expected to improve the productivity of the chronically inefficient collective farming inherited from the Soviet era. Improvements were to be achieved through the transfer of land and assets from collective farms to individual operators, in line with the established practice of agriculture in market economies. This study examines the progress of agricultural reform in Turkmenistan by focusing on land distribution, farm structure transformation, and changes in production patterns, marketing, and farm performance. The study is based on a survey of 143 private farmers conducted in Turkmenistan in 2000. Preliminary results indicate that, despite fairly generous allocation of land to individual farming, no significant performance improvements have been achieved so far, primarily because private farmers operate under severe environmental, institutional and political constraints.
\end{abstract}

\section{Overview of Land Reform in Turkmenistan}

Turkmenistan is a highly agrarian country, over half of the population is rural, and $44 \%$ of the labor force is employed in agriculture. Agriculture is the second most important sector in the Turkmen economy after the oil and gas industry. The territory of Turkmenistan is largely desert with irrigated arable land constituting less than $4 \%$ of the total. The most important cash crops are cotton and wheat; cotton is exported after processing into fiber while wheat is consumed domestically. Turkmenistan also produces livestock, as well as fruits and vegetables for domestic consumption.

Prior to the declaration of independence in 1991, Turkmenistan was one of the least developed republics in the Soviet Union and its agriculture was based on cotton monoculture. After 1991, Turkmenistan began raising wheat production, to reduce its dependence on food imports from former Soviet republics, which also had become independent states with independent interests and trade policies (Lerman and Brooks 1998).

Turkmenistan is the only country in Central Asia in which the post-Soviet constitution formally recognized private land ownership. The Constitution, however, only sets general principles, while the definition of ownership as well as practical implementation are left to laws, presidential decrees, and government resolutions. As a result, the actual rights of landowners in Turkmenistan are similar to those of landholders in "lifetime inheritable possession" according to the Soviet Civil Code in the pre-1990 era. Although land received for private farming is classified as privately owned, it cannot be sold, given as a gift, or exchanged. In addition, if privately owned agricultural land is left uncultivated, the owners may lose their private property through administrative measures (Lerman and Brooks 1998).

Prior to the adoption of the new Constitution of May 1992, all land in Turkmenistan was state-owned. Over $95 \%$ of the arable land was permanently used by 576 large-scale farms (1,500-2,500 hectares on the average) and

Readers with comments or questions are encouraged to contact the authors via email. 
around $2 \%$ were allocated in lifetime inheritable possession to rural households (less than 0.2 hectare on the average). The latter produced 20\% of gross agricultural product. Land reform started in 1993 with the conversion of household plots from inheritable possession into private ownership. At the same time virgin and unutilized land was transferred from the State Land Fund to private ownership and long-term leases (10-99 years, mainly 10-20 years) of individual farmers.

The agrarian reform program in Turkmenistan combined the recognition of the acknowledged benefits of individual farming with the deeply rooted socialist belief in economies of scale and in the associated central control tools (for details see Lerman and Brooks (1998, 2001), Mkrytichyan et al. (2000), and O'Hara (1997)). In accordance with these principles, in 1995 the traditional collective and state farms were reorganized into 570 associations of leaseholders (daikhan berleshik, or peasant associations). Each leaseholder was allocated state-owned arable land for individual production within the umbrella of the association. Yet the government maintained state procurement orders, especially for the two strategic commodities - cotton and wheat, supplementing it with an extensive system of subsidized inputs and credits. The leaseholders received land for individual production, but no freedom of deciding what to produce. Legislation passed in 1996 facilitated the leasing of land from peasant associations to their members, and in the following year there was a dramatic shift from collective farming in the associations to member leasing. The majority of association farmland is now leased to members. After a two-year probation period, farmers may be given full ownership if the land has been used productively. By contrast, the lease may be revoked if land is not used productively.

In a parallel strand of reform, Turkmenistan encouraged the establishment of so-called peasant (daikhan) farms - independent family farms operating outside associations and enjoying relative freedom from state orders. This freedom, however, had a price: the private farmers were given virgin land in the desert and were required to convert it by themselves into productive irrigated land within two years. Land quality was intended to differentiate private farmers from leaseholders, who received irrigated land within the bounds of their associations. While the conversion of former collective and state farms into leaseholder associations was a unique Turkmen procedure (with some analogies observed only in Uzbekistan), the creation of peasant farms outside traditional collectivist frameworks is a general agrarian reform strategy used in all former Soviet republics.

The present article focuses on the peasant farms of Turkmenistan. It is based on the results of a survey conducted in 2000 on a sample of 143 peasant farmers in four of the five administrative regions Turkmenistan. After a general discussion of the emergence of private farming in Turkmenistan, we present a preliminary analysis of survey findings and try to answer the question posed in the title: Does land reform, as represented by the new subsector of private farms, work in Turkmenistan? Figures and tables given without an explicit source are based on original survey data.

\section{Emergence of Peasant Farms in Turkmenistan}

The creation of private farms in Turkmenistan was enabled by legislation adopted in 1992-1996. According to the 1993 presidential decree, Turkmen citizen could apply to receive without any payment up to 50 ha of land in private ownership for individual commercial farming. This land, however, was not necessarily arable or irrigated. The presidential decree specifically stipulated that local authorities would allocate land plots for individual commercial farming from reserve lands, virgin lands, and lands not used by farm enterprises (which later became peasant associations). The new farmers were thus expected to "open" virgin lands by their own efforts and using their own resources. Yet the new farmers were in the danger of losing their land if they failed to start farming commercially within two years. The stipulation was probably unrealistic, given the tremendous difficulties that individuals would face in "opening" virgin lands and providing irrigation in the desert. Nevertheless, such "opening" of virgin lands by private farmers since 1993 (115,000 hectares, or $0.3 \%$ of all agricultural land) accounts for part of the considerable increase in the irrigated area observed during the recent years. The hardship associated with allocation of virgin lands was partially offset by exempting peasant farmers from taxation for the first five years and making them eligible to receive credit at low interest rates much below the rate of inflation. 
Of the 115,000 hectares transferred to peasant farmers as of January 2000, 90,200 hectares are in private ownership and 24,800 hectares are in long-term leases. The fastest pace of land allocation to peasant farming was observed during the first three years after the 1993 decree: $93 \%$ of land in private ownership and 59\% of the land under long-term leases was allocated up to 1996. During 1996-2000, the land allocated in private ownership increased by a mere 700 hectares and the leased component increased by 8,800 hectares (Figure 1).

According to land records, there were 7,066 peasant farms at the end of 1999. However, only 2,039 farms were registered with the state statistical agencies, and 1,103 provided reports about their activity. These 1,103 peasant farms are the actively producing component of the private farming sector in Turkmenistan, and the 143 peasant farms included in the survey represent $13 \%$ of the report providers.

The threat of losing land if it remains uncultivated for more than two years is quite real. In total, peasant farmers have lost nearly 25 thousand hectares due to failure to meet the startup conditions. This happened because in many cases the land received from the state required significant investment due to poor quality and remote location, and not everyone had the necessary financial and technical resources for developing this land.

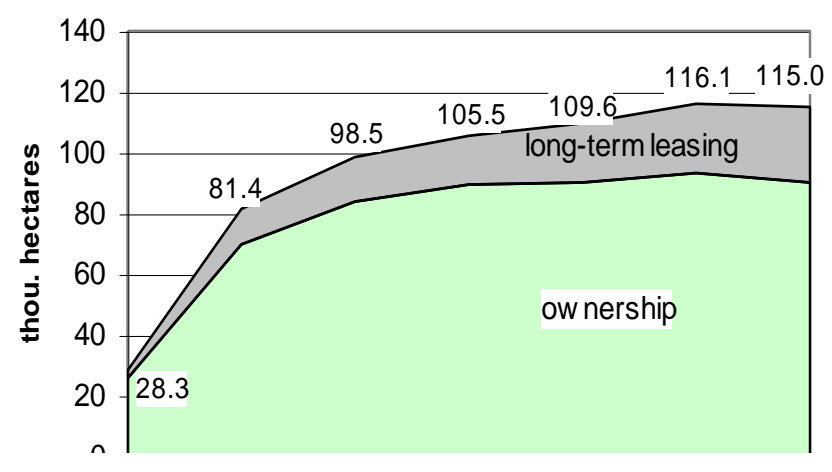

Figure 1 Dynamics of land allocation for creation of private farms (based on official statistics).

\section{Peasant Farms in the Survey}

The survey provides farm-level information about resources and farming activities, as well as the demographic profile of the families of peasant farmers.

\subsection{Family profile}

The overwhelming majority of farmers in the survey are men (95\%). The average farmer is 48 years old, while the average age of all family members is about 30 . The mean family size in the sample is 5.6 persons. The educational attainment of farmers is quite high: $58 \%$ of respondents report higher education and only 5\% have less than 10 years of schooling. This is in a dramatic contrast to the rest of the rural population, where according to a parallel survey only $10 \%$ report higher education, while $85 \%$ have secondary school background (Lerman and Stanchin 2001). Men generally have a higher educational attainment than women in rural households. Figure 2 shows clear gender differences in the level of education between men and women in farmers' families: most women have secondary education, while men generally continue to acquire some higher education.

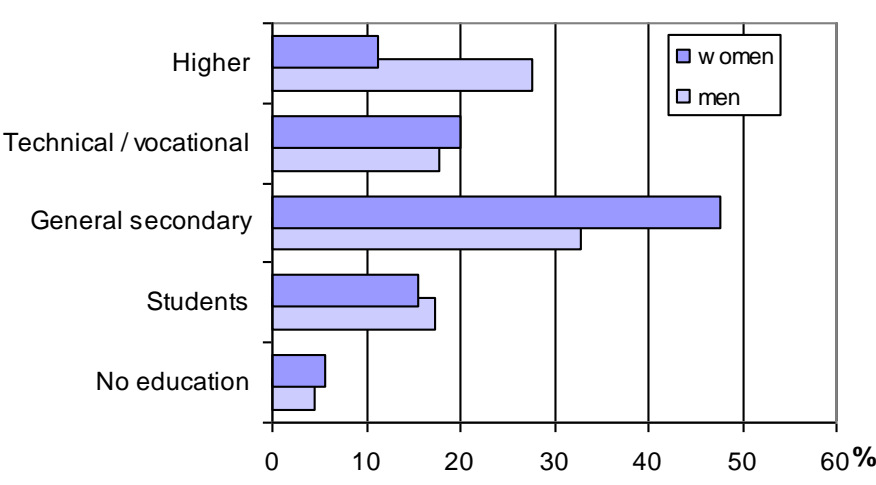

Figure 2 Education level of family members above 15

About 56\% of the farmers surveyed previously worked in a farm enterprise (a collective or state farm); the rest worked in industry or services outside agriculture. Farmers had held relatively high positions in their former jobs: $65 \%$ of respondents had had managerial or professional jobs, $10 \%$ described themselves as qualified workers, 
and $15 \%$ as administrative staff in their previous position. Private farmers thus bring with them a rich agricultural experience and a high educational attainment to their new occupation.

The land allocated to private farmers is usually far from the village, often in the middle of the desert. As a result, only $14 \%$ of respondents live with their families on the territory of the farm, while $57 \%$ continue to live in the village run by the peasant association with which the farm is administratively linked and $29 \%$ are domiciled in other villages or townships (Table 1). The rural housing is generally deficient in basic amenities. Nearly half the respondents have no running water, no electricity, and no gas in the house. Electricity is reported by $30 \%$ of private farmers, gas by $12 \%$, and running water by $4 \%$ only.

Table 1 Where does the family live?

\begin{tabular}{|l|c|c|c|}
\hline & All farms & $\begin{array}{c}\text { Farms using } \\
\text { own land }\end{array}$ & $\begin{array}{c}\text { Farms using } \\
\text { leased land }\end{array}$ \\
\hline On the territory of the farm & 14.1 & 22.4 & 8.3 \\
In the village of the peasant association & 57.0 & 37.9 & 70.2 \\
In another village & 6.3 & 8.6 & 4.8 \\
In the district center & 19.0 & 27.6 & 13.1 \\
Other & 3.5 & 3.4 & 3.6 \\
\hline
\end{tabular}

\subsection{Land}

Among the 143 farms surveyed, 60 had land allocated in private ownership and 83 were using leased land. None of the farms reported using both own and leased land. This essentially is a reflection of the existing institutional arrangements for land allocation in Turkmenistan, where the decision on whether land is given in private ownership or leased does not depend on the applicant: it is decided by government land authorities on the basis of certain political considerations, which are totally non-transparent to outsiders.

Farm sizes varied from 1 hectare to 370 hectares, but most farms (88\%) did not exceed 50 hectares, which is the legal limit for privately owned land. Farms based on own land averaged 19 hectares, whereas farms using leased land reached larger sizes, averaging 39 hectares. Most of the land is arable (68\%), with $0.2 \%$ under perennials and $27.5 \%$ in pasture. Other land constitutes $4.6 \%$ and is not used actively.

Land allocated to peasant farms was classified in three quality categories: 1 - land of satisfactory quality prepared for cultivation, 2 - land prepared for irrigation but requiring further amelioration, and 3 - unprepared virgin land. In line with existing legislation, a large share of land allocated to farmers in the survey was unprepared virgin land from state reserves, which required a large investment in improvement and amelioration. Farmers receiving land in private ownership ended up with much more virgin land than farmers who were given land in long-term lease (Figure 3). Officials probably give the worst land in private ownership, while for the time being retaining better lands in the state reserve.

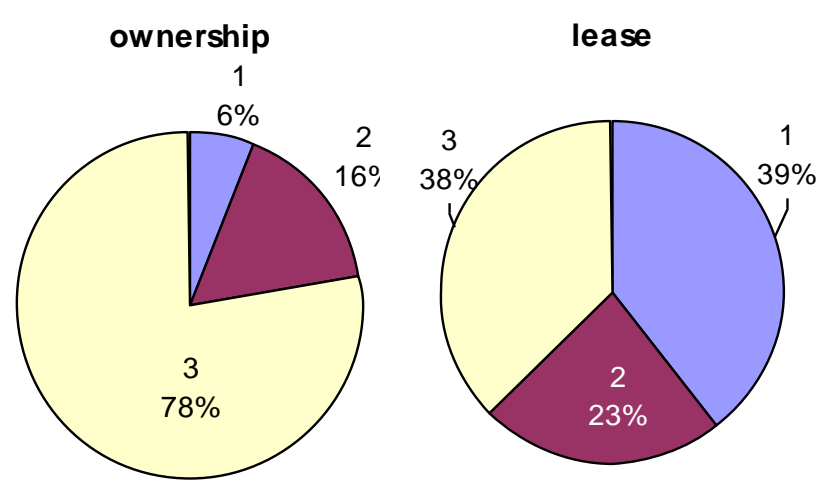

Figure 3 Quality of land allocated to peasant farms in private ownership and in long-term lease:

1 - land of satisfactory quality prepared for cultivation, 2 - land prepared for irrigation but requiring further amelioration, 3 - unprepared virgin land 
In general, farmers were satisfied with the quality of land they had received, although ameliorative improvements were required for $61 \%$ of land received in private ownership and $22 \%$ of arable land given in long-term lease. Land improvement normally involves leveling rough native terrain, moving large volumes of sand, trucking in equally large volumes of fertile soil from afar, and providing irrigation ditches or pipes from relatively distant water sources. The average cost of development of 1 hectare for the farmers surveyed was about 650 thousand manats ${ }^{1}$, i.e., $\$ 125$ at the official rate of exchange and about $\$ 30$ at the free-market rate. This is about one-third of the annual net profit per hectare of cotton, but more than two years of profits from wheat production (see Table 5 below for details). In spite of the investment so far, half the arable land in the sample still requires radical improvement. This was reported by $72 \%$ of respondents, but only half the farmers said they could afford the cost of land improvement work in the coming 3 years. The main obstacles for improvement are lack of money and machinery (two-thirds of respondents who would not be able to invest in land improvement).

Less than half the respondents reported cultivating their entire land holdings. The main reason for underutilization of land is lack of means for land development, as reported by $41 \%$ of respondents. Among other reasons, $19 \%$ of farmers noted difficulties with access to farm supplies and machinery, $25 \%$ complained about absence or irregularity of irrigation.

\subsection{Irrigation}

Under the prevailing climatic conditions in Turkmenistan, irrigation is indispensable to agriculture and it was developed extensively throughout the cultivable parts of country in the Soviet times. Surface irrigation remains the dominant technique, although micro-irrigation is being introduced on an experimental scale (in 1994, microirrigation covered a mere 400 hectares, or $0.02 \%$ of total irrigated area) All the main canals, major parts of the interfarm and intra-farm irrigation networks, and all the collector and drainage networks are above the ground. With such irrigation systems, water loss is up to one-fifth of the intake due to seepage and evaporation (Orlovsky et al. 2001). Yet practically all the respondents $(97 \%)$ consider furrow irrigation as the most effective method, probably because they do not know any other irrigation methods.

All private farms have access to an external irrigation network or at least to local water sources. Thus, $62 \%$ receive water from man-made irrigation networks, $30 \%$ of farms irrigate their fields from wells, rivers, or other local water sources, and $8 \%$ access other water sources. The distribution of water sources is different for farms based on own land and farms using leased land (Table 2). These differences may affect the quality of water (salinization, contamination).

Although all private farms have access to water, only $20 \%$ of farms report receiving water on time and even then much less than the required norms (Table $3)$. It is hard to expect high yields in the desert under such conditions: expert estimates show that reduction of watering by $10 \%, 20 \%, 30 \%, 40 \%$, or $50 \%$ reduces crop yields by $4 \%, 9 \%, 15 \%, 24 \%$, or $36 \%$, respectively (Khamidov et al. 2001). Farmers try to compensate for these shortages by using mineralized water from drainage collectors, lakes, and ground sources. Irrigation with saline water worsens soil quality and depresses

Table 2 Sources of water for irrigation, \% of respondents

\begin{tabular}{|l|c|c|c|}
\hline \multirow{2}{*}{} & \multicolumn{3}{|c|}{ Water sources } \\
\cline { 2 - 4 } & local & $\begin{array}{c}\text { man-made } \\
\text { networks }\end{array}$ & other \\
\hline All farms & 29.4 & 62.2 & 8.4 \\
Farms using own land & 16.7 & 81.7 & 1.7 \\
Farms using leased land & 38.6 & 48.2 & 13.3 \\
\hline
\end{tabular}

Table 3 Actual waterings in percent of the norm

\begin{tabular}{|l|c|c|c|}
\hline & All farms & $\begin{array}{c}\text { Farmers } \\
\text { using own } \\
\text { land }\end{array}$ & $\begin{array}{c}\text { Farmers } \\
\text { using } \\
\text { leased land }\end{array}$ \\
\hline Cotton & 55.0 & 75.7 & 50.3 \\
Wheat & 55.0 & 56.0 & 54.4 \\
Vegetables & 67.6 & 71.8 & 58.1 \\
Alfalfa & 63.3 & 68.3 & 50.0 \\
Gardens & 56.7 & 56.5 & 57.1 \\
Vineyard & 90.0 & 100.0 & 80.0 \\
\hline
\end{tabular}

${ }^{1}$ The national currency, the manat, was introduced in November 1993 with the initial rate $\$ 0.5$ for 1 manat. The currency depreciated rapidly. In April 1998, the currency was pegged at 5200 per dollar, close to the market rate. Since then the government has maintained the official rate despite strong excess demand for foreign currency. The parallel exchange rate fell precipitously to over three times the official rate by mid 1999 and to four times the official rate by late 2000 . 
crop yields. At present $80 \%$ of Turkmenistan's irrigated soils are saline, and salinization reduces output by $40 \%$ (Khakimov 1986). During fall-winter, special activities are required to flush the salt from the soil.

No private irrigation schemes exist in Turkmenistan. All are managed by a state agency, and they are generally larger than 10,000 hectares, having been originally designed and built for large collective and state farms. Among the respondents in the survey, only $6 \%$ own their irrigation equipment and $6 \%$ are responsible for maintaining the irrigation network. Water is allocated to each farm on the basis of standard crop requirements. If a farm exceeds its allocation, a fine is applied, based on the excess water usage. In 1995, the fine was 0.503 manat $/ \mathrm{m}^{3}$, or 20 cents per $1,000 \mathrm{~m}^{3}$. This is a symbolic charge that does not reflect the real value of water. Moreover, the fine is hardly ever applied, because the inefficient and insufficient irrigation prevents farmers from receiving even the minimum amounts of water.

\subsection{Farm Production}

Practically all peasant farmers engage in crop production (Table 4). Livestock is reported by a much smaller proportion of farms: less than $20 \%$ of respondents have mixed crop-livestock farming, and only $5 \%$ specialize in livestock without any crop production. About $80 \%$ of farms grow wheat, although wheat production is substantially less profitable than cotton (Table 5). By contrast, among leaseholders in peasant associations (former collective or state farms) surveyed in a previous study (Lerman and Brooks 2001), $80 \%$ grow cotton and only $20 \%$ grow wheat. Authorities do not explicitly prescribe what private farmers must produce, while the production specialization of leaseholders in peasant associations is strictly controlled. However, cotton cannot be grown without irrigation, whereas many private farms established on virgin land still suffer from shortage of water. Farms using leased land have better access to local water sources, such as wells and rivers (see Table 2), which are more reliable than the poorly maintained man-made irrigation networks. Better access to water probably explains the higher tendency of these farms to grow cotton (Table 4). Cotton production also requires ten times more labor per ton than wheat (Guchgeldiev 1999), which may be a barrier to the adoption of cotton in family-based private farms.

Table 4 Specialization profile of peasant farmers (\% of respondents)

\begin{tabular}{|l|c|c|c||c|c|c|}
\hline & Crops & Livestock & $\begin{array}{c}\text { Crops and } \\
\text { livestock }\end{array}$ & Wheat & Cotton & Vegetables \\
\hline All farms & 77.6 & 4.9 & 17.5 & 81.0 & 29.4 & 11.2 \\
Farms using own land & 70.0 & 10.0 & 20.0 & 83.3 & 11.7 & 16.7 \\
Farms using leased land & 83.1 & 1.2 & 15.7 & 78.3 & 42.2 & 6.0 \\
\hline
\end{tabular}

Table 5 Comparative costs and profit of wheat and cotton production in 1999 (national data).

\begin{tabular}{|c|c|c|c|c|}
\hline & \multicolumn{2}{|c|}{ Peasant associations } & \multicolumn{2}{|c|}{ Private farms } \\
\hline & Cotton & Wheat & Cotton & Wheat \\
\hline Sown area, thousand ha & 500.9 & 610.9 & 13.6 & 6.8 \\
\hline Yield, ton/ha & 1.69 & 1.53 & 3.60 & 1.51 \\
\hline Gross output, thousand ton & 844.9 & 937.2 & 48.9 & 10.2 \\
\hline Revenue, billion manat & 786.4 & 397.6 & 48.8 & 4.3 \\
\hline Total costs, billion manat & 266.4 & 243.4 & 21.4 & 2.5 \\
\hline Total profit, billion manat & 520,0 & 154.2 & 27.4 & 1.8 \\
\hline Costs per 1 ton, thousand manat & 315.0 & 260.0 & 437.0 & 245.0 \\
\hline Costs per 1 hectare, thousand manat & 532.0 & 398.0 & 1573.0 & 367.0 \\
\hline Profit per 1 hectare, thousand manat & 1038.0 & 252.0 & 2014.0 & 264.0 \\
\hline
\end{tabular}

Source: Lerman and Stanchin, 2001.

Livestock production (whether specialized or as part of mixed farming) appears to be more widespread among farmers using own land than among those with leased land (see Table 4). Yet the average cattle herd is much larger on farms using leased land: 41 head of cattle compared with 18 head of cattle for farms operating on own land. The opposite is true with respect to poultry, which is more popular among farmers operating on own land: $61 \%$ 
of the own farms versus $24 \%$ of leased farms. The average flock is also much larger - 638 chickens in farms with own land versus only 49 in farms using leased land. Sheep and goats, the traditional animals in Turkmenistan, are reported by less than one-third of farmers with livestock ( $8 \%$ of all farms surveyed). Livestock productivity that emerges from survey data is very low (Table 6) and it is generally comparable with the productivity reported by leaseholders in peasant associations, who achieve milk yields of about 1,200 $\mathrm{kg}$ per cow per year and egg laying capacities of about 70 eggs per layer per year (Lerman and Brooks 2001).

The various reasons given by respondents for not going into livestock production mainly reflect capital constraints. Thus, $68 \%$ of farmers lack the means to purchase animals, $54 \%$ lack facilities for keeping livestock and poultry, and 38\% experience difficulties with machinery and purchased inputs.

Table 6 Herd/flock size, livestock production (per one farm) and productivity (per one animal)

\begin{tabular}{|l|c|c|c|c||c|c|c|c|c|}
\hline & \multicolumn{3}{|c||}{ Average herd/flock size, heads } & \multicolumn{3}{c|}{ Production } & \multicolumn{3}{c|}{ Productivity } \\
\cline { 2 - 10 } & Cattle & $\begin{array}{c}\text { Including } \\
\text { cows }\end{array}$ & $\begin{array}{c}\text { Sheep } \\
\text { and goat }\end{array}$ & Chickens & $\begin{array}{c}\text { Meat, } \\
\text { tons }\end{array}$ & $\begin{array}{c}\text { Milk, } \\
\text { tons }\end{array}$ & $\begin{array}{c}\text { Eggs, } \\
\text { pieces }\end{array}$ & $\begin{array}{c}\text { Milk, } \\
\text { kg }\end{array}$ & $\begin{array}{c}\text { Eggs, } \\
\text { pieces }\end{array}$ \\
\hline All farms & 30.3 & 11.2 & 106.2 & 454.2 & 1.73 & 11.00 & 17505 & 1219 & 95 \\
Farms using own land & 17.6 & 7.8 & 117.0 & 638.5 & 1.86 & 10.19 & 25546 & 967 & 91 \\
Farms using leased land & 40.9 & 14.2 & 95.3 & 49.0 & 1.81 & 13.06 & 4103 & 1507 & 105 \\
\hline
\end{tabular}

The private farmers show a high degree of commercialization. Most of the output is sold. This includes all the cotton, $85 \%$ of wheat, $90 \%$ of grapes, and about $60 \%$ of livestock production (milk, meat, and eggs). On the other hand, more than half the output of vegetables and melons are consumed in the household.

\subsection{Farm Services: Marketing and Input Supply}

Until 1996 all agricultural services, including input supply, processing, and marketing, were the responsibility of the Ministry of Agriculture and Food. After 1996, the responsibility for the main farm services was transferred from the Ministry to a number of autonomous state-controlled service organizations specializing in various farm-related services. Among these parastatals, Turkmenobakhyzmat is responsible for the provision of all services related to the use of machinery, Turkmenpagta provides inputs for cotton production and is responsible for cotton marketing, Turkmengalla is the wheat purchasing agency, and Turkmenmallary controls livestock-related services (including actual ownership of some sheep herds). In addition to managing the flow of services to independent peasant farmers and to leaseholders in peasant associations, these organizations also collect the state subsidies that allow farmers to pay only half price for all inputs, such as machinery, seeds, fertilizers, and herbicides.

Although private farmers have never been subject to any state orders for the production of wheat and cotton, they were originally obligated to sell these strategic commodities to the two parastatals, Turkmengalla and Turkmenpagta, which paid prices far below world market prices, while at the same time subsidizing 50\% of input costs. In the late 1990s, producers received only about $40 \%$ of the market value of their wheat and cotton, while the input subsidies offset between one-third and one-half of this negative difference (Lerman and Brooks 2001). Agricultural producers in Turkmenistan are thus heavily taxed by the government's price policies. Since June 1996, private farmers are allowed to sell wheat and cotton at freely negotiated prices on the State Commodity Exchange and, in the case of wheat, also in the open market. However, such free sales involve forgoing the input subsidy. Table 7 shows that only a small percentage of respondents channel their wheat and cotton sales through the Commodity Exchange, and most sales continue to be directed to the parastatals, presumably in the interest of securing the substantial input subsidies. Nevertheless, over $20 \%$ of wheat sellers report selling their grain in the open market, which is also the main outlet for the unregulated products, such as vegetables, meat, and milk. Since most cotton and wheat is sold through parastatals, over $80 \%$ of producers complain that the prices they receive are too low. Many also complain about delays in payment by the marketers ( $75 \%$ of cotton producers and $44 \%$ of wheat producers). 
Table 7 Channels of sales (\% of respondents)

\begin{tabular}{|l|c|c|c|c|c|c|}
\hline & Wheat & Cotton & Vegetables & Melons & Meat & Milk \\
\hline Parastatal marketing agencies & 71.4 & 97.2 & -- & -- & -- & 3.8 \\
Market and consumers & 21.0 & -- & 77.8 & 80.0 & 77.3 & 88.5 \\
State Commodity Exchange & 5.7 & 2.8 & 22.2 & 20.0 & 9.1 & 3.8 \\
\hline
\end{tabular}

Many of the farmers who received land from the state did not have the necessary farm machinery and generally could not afford to buy it. Half the farmers surveyed actually own production assets of one kind or another including machinery and equipment, farm buildings, and other. Own machinery is reported by $35 \%$ of farmers; $30 \%$ of respondents own tractors, and $12 \%$ own trucks. The average farm has 1.1 units of machinery of any kind, and the area serviced by one unit is 19 hectares. The available own machinery is not sufficient for actual farm needs. Most farmers, both with and without own machinery, purchase mechanized field services and transport services from outside sources (Table 8). As a result, despite the limited spread of machinery ownership among farmers, practically everybody has access to machinery services through rental arrangements with parastatals and even private service suppliers (Table 9).

Table 8 Machinery ownership and purchase of machinery-related services by farmers

\begin{tabular}{|l|c|c|c|}
\hline \multirow{2}{*}{} & \multirow{2}{*}{$\%$ of farmers } & \multicolumn{2}{|c|}{ \% of them purchasing } \\
\cline { 3 - 4 } & & mechanizes field services & transport services \\
\hline Farmers with any own machinery & 35.0 & 72.0 & 65.0 \\
\hline Farmers without own machinery & 65.0 & 91.4 & 88.2 \\
\hline
\end{tabular}

The farmers use the standard range of purchased inputs and farm services. Over $90 \%$ of farmers in the survey purchase fertilizers, seeds, and machinery-related services (Table 9). Inputs specific to livestock production are purchased by a relatively small subgroup of respondents, as livestock production is infrequent in the sample. Key inputs are provided by parastatals at $50 \%$ discount, but access to subsidies is tied to fulfilling state orders. Since private farmers generally do not produce under state orders, parastatal agencies are not the dominant source for the supply of farm inputs in the survey. Despite the obvious importance of state agencies as input suppliers, more farmers buy their inputs from other private individuals or private commercial firms than from parastatals (except for fertilizers and seed; see Table 9). This is a clear indication of an emergent market system for farm inputs despite the strict government control in Turkmenistan. Peasant associations are of marginal importance as suppliers of farm inputs and provide mainly herbicides, veterinary services, and consulting, which are used by a small proportion of farmers. On the whole, farmers do not report major difficulties with purchasing farm inputs and services. The main complaint concerns high prices and lack of funds.

\subsection{Banking and Credit}

Banking to agriculture in general and to private farmers in particular is the monopoly of the state-controlled Daikhan Bank (i.e., Peasant Bank in English translation). Private farmers are allowed to hold individual accounts and to conduct financial transactions with Daikhan Bank only. Credit to farmers is provided exclusively through special government programs administered by Daikhan Bank. Not surprisingly, over $40 \%$ of respondents are dissatisfied with the service they receive from this monopolistic financial institution.

Investment and working capital financing is provided to private farmers through special government programs, which are characterized by deeply negative real interest rates and high levels of credit targeting. Those who accept state orders for wheat and cotton receive credit against the future harvest at $1 \%$ interest rate (in an environment where inflation averaged $21 \%$ in 1998-99, after subsiding from more than $1000 \%$ annually in 1993-1995). These credits are in addition to the 50\% input subsidy, and they cover $35 \%$ of total wheat production costs and $25 \%$ of cotton production costs (Lerman and Stanchin 2001). Independent private farmers and other agricultural producers operating without state orders are also entitled to subsidized credit, but they have to pay 8-10\% nominal interest rates (Presidential decree No. 3626, March 4, 1998). This is higher than for producers working under state orders, but still deeply negative in real terms. 
Table 9 Purchase of farm inputs and services (percent of farmers)

\begin{tabular}{|c|c|c|c|c|c|c|c|c|}
\hline \multirow{2}{*}{ Inputs and services } & \multirow{2}{*}{$\begin{array}{c}\text { Farmers } \\
\text { purchasing } \\
\text { the input, \% }\end{array}$} & \multicolumn{4}{|c|}{$\begin{array}{l}\text { Source of supply (percent of those who buy the } \\
\text { specified input)* }\end{array}$} & \multicolumn{3}{|c|}{ Difficulties with purchase of inputs } \\
\hline & & $\begin{array}{c}\text { State } \\
\text { supplier }\end{array}$ & Associations & Individuals & $\begin{array}{c}\text { Own } \\
\text { production }\end{array}$ & $\begin{array}{c}\text { No prob- } \\
\text { lems }\end{array}$ & High prices & $\begin{array}{l}\text { Lack of } \\
\text { funds }\end{array}$ \\
\hline Seeds and seedlings & 94 & 43 & 7 & 10 & 39 & 84 & 12 & 1 \\
\hline Feed & 37 & 6 & 9 & 28 & 55 & 21 & 17 & 57 \\
\hline Young animals & 32 & 2 & 2 & 33 & 54 & 21 & 9 & 68 \\
\hline Fertilizers & 92 & 55 & 11 & 20 & 2 & 43 & 37 & 6 \\
\hline Manure & 88 & 9 & 9 & 16 & 49 & 73 & 7 & 13 \\
\hline Herbicides & 34 & 31 & 41 & 27 & -- & 20 & 13 & 39 \\
\hline Farm machinery & 72 & 31 & 13 & 46 & 4 & 22 & 23 & 31 \\
\hline Repairs, maintenance & 52 & 22 & 3 & 47 & 16 & 15 & 24 & 48 \\
\hline Spare parts & 52 & 11 & 3 & 82 & -- & 3 & 35 & 46 \\
\hline Fuel & 58 & 46 & 2 & 47 & -- & 26 & 15 & 36 \\
\hline Mechanized field services & 93 & 40 & 8 & 40 & 10 & 7 & 31 & 54 \\
\hline Transport services & 91 & 41 & 5 & 42 & 9 & 38 & 34 & 8 \\
\hline Veterinary drugs & 22 & 6 & 6 & 81 & 35 & 31 & 31 & 3 \\
\hline Veterinary services & 30 & 19 & 28 & 42 & 5 & 6 & 13 & 67 \\
\hline Construction materials & 13 & 6 & 6 & 72 & -- & 22 & 10 & 59 \\
\hline Construction services & 20 & 4 & 4 & 39 & 4 & 4 & 23 & 67 \\
\hline Expert consulting & 29 & 29 & 27 & 34 & 2 & 33 & 3 & 51 \\
\hline
\end{tabular}

* May add up more than $100 \%$ because the farmers use multiple sources of supply.

Active borrowing - beyond automatic credit for inputs from the Daikhan Bank - is extremely limited among private farmers. Nearly two-thirds of the respondents indicated that they were unable to get any credit. As the main reasons for such severe credit constraints they cited technical complexity of the loan- application system and inability to provide satisfactory collateral due to the absence of mortgage facilities (Table 10). Credit availability does not appear to be a strong constraint.

Less than $10 \%$ of respondents reported actual borrowing in 1999. These few borrowers received loans mainly from formal sources - from state and commercial banks (Table 11). Contrary to smallholders in some other countries, such as Armenia and Georgia, Turkmen farmers do not show special reliance on relatives as a source of loans: a higher percentage of respondents borrow from banks than from relatives. Loans received from banks are larger than informal loans from relatives, and they naturally carry an interest charge. Interest rates from commercial banks are higher than from state banks, and not always negative in real terms. The average loan obtained from banks was 43,800 thousand manat, which is approximately equal to one year of sales for the farmers who borrow.

Table 11 Sources of credit, loan amounts, and interest rates for private farmers in 1999

\begin{tabular}{|l|c|c|c|}
\hline & \% of farmers reporting borrowing & Average loan amount, thousand manat & Interest rate, \% \\
\hline From all sources & $9.1^{*}$ & 34,500 & n.a \\
State bank & 3.5 & 47,900 & $2-15$ \\
Commercial banks & 3.5 & 37,000 & $10-36$ \\
Relatives & 2.8 & 27,333 & 0 \\
Other individuals & 0.7 & 1,800 & 5 \\
\hline
\end{tabular}

* This is less than the sum of all sources because one farmer borrowed from three sources.
Percent of respondents among rmers unable to get credit

40.4

14.9

36.2

8.5 


\subsection{Outcomes}

Despite the rapid growth in the area and the number of private farms since 1993, they account for a very small percentage of agricultural land and agricultural output in Turkmenistan (Table 12). Private farms control onethird of one percent of agricultural land and about $1 \%$ of arable land in the country. Cattle herds on private farms increased three-fold between 1997-99, but they still represent merely one-third of one percent of the total number of cattle in the country and about one-tenth of one percent of meat and milk production. The share of private farms in grain and cotton production is higher, approaching $1 \%$ of the country's total, but it is marginal by all counts.

Table 12 Share of private farmers in agricultural land and agricultural output in Turkmenistan

\begin{tabular}{|c|c|c|c|c|c|c|c|c|}
\hline Year & $\begin{array}{l}\text { Number of } \\
\text { farmers }\end{array}$ & $\begin{array}{c}\text { Total area } \\
\text { allocated to } \\
\text { private farms, } \\
\text { thou. ha }\end{array}$ & $\begin{array}{c}\text { Share of } \\
\text { private farms } \\
\text { in agricultural } \\
\text { land, } \%\end{array}$ & Cattle & Meat & Milk & Grain & Cotton \\
\hline $\begin{array}{l}1993 \\
1994 \\
1995 \\
1996 \\
1997 \\
1998 \\
1999\end{array}$ & $\begin{array}{c}750 \\
3407 \\
4991 \\
5636 \\
6117 \\
6809 \\
7066\end{array}$ & $\begin{array}{c}81.4 \\
98.5 \\
105.5 \\
109.6 \\
116.1 \\
115.0\end{array}$ & $\begin{array}{l}0.25 \\
0.30 \\
0.33 \\
0.34 \\
0.36 \\
0.35\end{array}$ & $\begin{array}{l}0.10 \\
0.13 \\
0.34\end{array}$ & $\begin{array}{l}0.084 \\
0.083 \\
0.087\end{array}$ & $\begin{array}{l}0.102 \\
0.096 \\
0.130 \\
\end{array}$ & $\begin{array}{l}0.47 \\
0.74 \\
0.68\end{array}$ & $\begin{array}{l}0.18 \\
0.80 \\
3.75\end{array}$ \\
\hline
\end{tabular}

Source: Lerman and Stanchin, 2001 for data about private farmers and that FAOSTAT on-line database for Turkmenistan's total production. No production data for private farms are available prior to 1997. Production shares of private farmers should be treated as very rough order-of-magnitude estimates, because they have been calculated as the ratio of numbers from two highly disparate sources.

So far, private farmers have not been able to achieve higher yields than peasant associations. As noted previously, milk yields range around 1,200 kg per cow per year both for private farms in the survey and for peasant associations. National data indicate that grain yields are somewhat lower for private farms than for peasant associations, while yields of vegetables and melons are much lower for private farms (Table 13). It is only in cotton that private farms show a certain advantage both in 1998 and 1999. These results are quite disappointing, especially in view of the fact that private farms emphasize grain at the expense of cotton (see Table 4 above).

Table 13 Crop yields in peasant associations and private farms (in tons per hectare)

\begin{tabular}{|l|c|c|c|c|}
\hline \multirow{2}{*}{} & \multicolumn{2}{|c|}{1998} & \multicolumn{2}{c|}{1999} \\
\cline { 2 - 5 } & Peasant associations & Private farms & Peasant associations & Private farms \\
\hline Cotton (raw) & 1.29 & 1.59 & 2.10 & 3.60 \\
Cotton fiber & 1.25 & 2.03 & 1.80 & 2.21 \\
Grain & 1.83 & 1.67 & 2.08 & 1.51 \\
Vegetables & 15.10 & 7.68 & 15.85 & 5.79 \\
Melons & 10.07 & 4.17 & 12.41 & 5.64 \\
\hline
\end{tabular}

Source: Lerman and Stanchin, 2001

Table 14 Financial performance of the private farms in the survey (in thousand manats per farm)

\begin{tabular}{|l|c|c|}
\hline & 1999 & 2000 est. \\
\hline Sales & 21,259 & 24,430 \\
Cost of production* & 9,989 & 10,486 \\
Gross profit & 11,270 & 13,944 \\
\hline
\end{tabular}

* Excluding family labor.
Although private farmers have not achieved higher productivity, their operations appear to be profitable (Table 14). In 1999, the average farm had a gross profit of $\$ 2,700$ at the official exchange rate ( $\$ 670$ at the free-market rate), which is about $55 \%$ of total sales revenue. The profitable operation of private farms is a significant achievement in view of the system of government controls that keeps the producer prices artificially below world market prices. 
Despite these positive outcomes of the process of reform, the private farmers have not had a measurable impact on the overall agricultural performance because of their marginal role in the country's agriculture. With $44 \%$ of the labor force employed in agriculture, the sector accounts for about $20 \%$ of GDP, which suggests that labor is still much less productive in agriculture than in other sectors of the economy. Turkmenistan still has a long way to go on the path of reform if it is to achieve significant improvements in productivity and efficiency of agriculture.

\section{Constraints for Private Farming in Turkmenistan}

The development of private farming in Turkmenistan is hampered by institutional, technological, and financial conditions. The main difficulties they face are unfavorable natural conditions (poor soil, scarce water, inefficient irrigation); lack of funds for purchasing inputs and undertaking farm operations; lack of necessary farm management skills; uncertain property rights; low government-controlled prices; and export barriers.

One potential advantage of transferring agricultural land to private ownership is to stimulate family investment in the farm. However, the new private farmers come from the ranks of former collective-farm workers, who were notoriously poor and did not bring with them any startup capital to the new venture. Moreover, the legal framework in Turkmenistan prohibits virtually all transactions in land, which suggests severely circumscribed ownership rights and uncertain security of tenure. Therefore, farmers are understandably reluctant to invest in their land, which is reflected in low willingness to borrow. Farmers are not investing in the development of higher yielding technologies and in quality seed stocks, while the state will remain unable to fund significant investments in agricultural in the foreseeable future. Altering priorities led to a reduction of state investment in agriculture. The capitalintensive oil and gas sector now dominates the government's investment priorities: its share in total investment increased from $9 \%$ in 1994 to $48 \%$ in 1999. The share of agriculture in total investment accordingly declined from 15\% in 1994 to a mere 2\% in 1999, although this sector employs almost half the population (Pomfret 2001).

The pervasive government intervention in agriculture imposes a heavy implied tax on producers. The government-controlled prices for the two strategic commodities - wheat and cotton - are so low that even the seemingly generous subsidies that farmers receive in the form of inputs and credit are insufficient to offset the extraction of funds from agriculture. Although recent legislation allowed some trade liberalization, the domestic market is limited domestically and individual farmers do not have access to export markets. In practice, most farmers are forced to sell to the state at prices much below world market prices for their products.

\section{Conclusion}

Commercial individual farming in Turkmenistan is conducted on privately owned or leased land using mainly family labor. In principle, private farmers have the right to decide what to produce and are allowed to conclude voluntary business contracts with legal entities or individuals for the sale of their products at freely negotiated prices. In practice, the pervasive system of government subsidies and interventions often prevents farmers from exercising these options.

Distribution of land for individual use and the introduction of private responsibility for production provide incentives to increase productivity and efficiency in agriculture. However, despite the growth in numbers and total area, private farms still cultivate only a small percentage of agricultural land and account for a minute share of agricultural production. Private farmers diligently open virgin lands without funds, skills, or machinery. They even manage to show a profit, although it may be inadequate given the risks involved in private farming in Turkmenistan. The land reform in Turkmenistan works, but it still has not produced measurable impacts on Turkmen agriculture.

\section{References}

1. Guchgeldiev, O. (1999). Comprehensive Economic Study of Cotton Production Sub-sector in Turkmenistan. M.Sc. Dissertation, The University of Birmingham. 
2. Khakimov, F. (1986). Desertification Processes and Soil Reclamation in the Downstream Area of the Amudarya, Proceedings of the 5th All-Union Conference on Ecological Problems of Desert Development and Nature Conservation, Ilym Publishing House, Ashkhabad [in Russian].

3. Khamidov, M., F. Baraev, and A. Allaviev (2001). Alternative strategies for Water Pricing and Water Conservation. In: P.C. Bloch and A.A. Kutuzov, eds., Rural Factor Market Issues in the Context of Agrarian Reform, BASIS, The Land Tenure Center, University of Wisconsin, Madison.

4. Lerman, Z. and K. Brooks (1998). Land Reform in Turkmenistan, in: S. Wegren, ed., Land Reform in the Former Soviet Union and Eastern Europe, Routledge, New York, Chapter 7.

5. Lerman, Z. and K. Brooks (2001). Turkmenistan: An Assessment of Leasehold-Based Farm Restructuring, World Bank Technical Paper No. 500, World Bank, Washington, DC.

6. Lerman, Z. and I. Stanchin (2001). Farm Restructuring and Land and Water Reform in Turkmenistan. AID Grant TA-MOU-98-CA17-011. Unpublished draft.

7. Mkrytichyan, L., A. Halnepesova, and J. Ataev (2000). Agricultural Policy Reforms and Food-Sufficiency in Turkmenistan. In: S. Babu and A. Tashmatov, eds., Food Policy Reforms in Central Asia: Setting the Research Priorities, International Food Policy Research Institute, Washington, DC.

8. O'Hara, S.L. (1997). Agriculture and Land Reform in Turkmenistan Since Independence, Post-Soviet Geography and Economics. 38: 430-444.

9. Orlovsky N., M. Glantz, and L. Orlovsky (2001). Irrigation and Land Degradation in the Aral Sea Basin. In: S.-W. Breckle, M. Veste, and W. Wucherer, eds., Sustainable Land Use in Deserts, Springer.

10. Pomfret, R. (2001). Turkmenistan: From Communism to Nationalism by Gradual Economic Reform, School of Economics, University of Adelaide.

Notes 